\title{
BYZANTINE STUDIES IN SPAIN. THE SPECIFIC CASE OF GRANADA
}

\author{
Maila García Amorós - Panagiota Papadopoulou
}

DOI: 10.17846/CL.2021.14.1.177-183

\begin{abstract}
GARCÍA AMORÓS, Maila - PAPADOPOULOU, Panagiota. Byzantine Studies in Spain. The Specific Case of Granada. Byzantine studies appeared relatively late in Spain compared to other European countries, where they had developed from the 17th century and found their culmination in the 19th century mainly in countries such as France, Germany and England. In Spain, it was not until the end of the 19th century that a few isolated philologists slowly began to turn their gaze to the Byzantine east. In the 20th century, some of the most important classical philologists began to include Byzantine authors as their subjects of study. However, the presence of philologists specialized in this area is relatively recent in Spain. The University of Granada was the first to introduce subjects related to history and Byzantine literature in Spain in the 1980s. The foundation of the Centre for Modern Greek and Cypriot Byzantine Studies of Granada in 1998 was an important boost for the development and systematization of this type of studies, not only in the Iberian Peninsula, but throughout the Hispanic area in general.
\end{abstract}

Keywords: Byzantine studies, Spain, Granada, research, teaching

The first signs of the interest of European philologists and scholars in the Byzantine world, as far as it is known, appeared at the end of the 16th century and especially at the beginning of the 17th century in Germany and was demonstrated in the edition of texts by Byzantine authors as well as in studies and monographs on its history. In the 20th century, Byzantine studies experienced a significant re-evaluation mainly in Germany, France and England, and later in Italy, Hungary, Russia, Czechia and Slovakia (Zozulak 2017). In Spain, Byzantine studies started to emerge quite late compared to the rest of Europe, and it was not until the last decades of the 19th century when Byzantine studies began to develop. The Catalan professor Antonio Rubió y Lluch (1856 1937) was one of the first Spanish teachers to turn his gaze towards Byzantium, interested in the relationship between Catalans and Greece, which he reflected in his work The Catalans in Greece: the last years of their domination, historical paintings. Professor Sebastián Cirac Estopañán (1903 1970) tried to make the first approach to the Byzantine world and to bring his knowledge to the

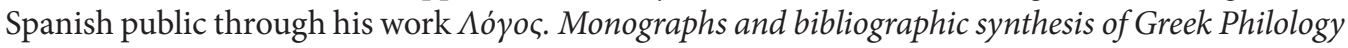
published in 1960. Somewhat later, classical philologists such as Manuel Fernández Galiano, Francisco Rodríguez Adrados and Antonio Tovar turned their gaze to the Byzantine world in their research (Fernández Galiano 1989). However, we owe the most important contributions to Medieval Greek language and civilization to Professor José María Egea Sánchez, whose studies on Medieval Greek language and literature constitute one of the first and most rigorous approaches to this field in the Spanish area (Bádenas de la Peña 1993). At the present time, there are some professors and researchers who specialize in the Byzantine period and they teach in various universities, such as Juan Signes Codoñer at the University of Valladolid, Ernest Emili Marcos Hierro at the Autonomous University of Barcelona, and José Soto Chica, researcher at the University of Granada and a specialist on the relations of Byzantium and the Muslim world. 
It should be noted that the presence of Professor Moschos Morfakidis Filactós in Spain, specifically at the University of Granada, laid down the more systematic development of the teaching and research of Byzantine and Modern Greek studies in the 1980s. At that time, the subjects of Medieval and Modern Greek language, literature and culture, conceived as the continuation and evolution of post-classical literature, were included in the study programme of the Classical Philology degree in the Faculty of Arts at the University of Granada. Other universities successively began to introduce Byzantine and Modern Greek Studies, such as the universities in Barcelona, Salamanca, Valencia, Tenerife, the Basque Country, Murcia, Valladolid and Cadiz.

A decisive impulse for Byzantine studies in Spain was undoubtedly the foundation of the Centre for Byzantine, Modern Greek and Cypriot Studies in Granada in 1998 (Centre of Byzantine, Modern Greek and Cypriot Studies 2013), which constitutes a fundamental pillar for the study and diffusion of Byzantine and Modern Greek language, literature and culture in Spain and Latin America. The Centre was established to provide an adequate response to the growing interest in this kind of studies, since at that time Spain lacked sufficient resources and tools for the development of Byzantine and Modern Greek Studies. The main objective of the foundation of the Centre for Byzantine Studies was to offer the necessary tools, not only to students - who virtually ignored the history and role of Byzantium in the history of Europe - but also to Spanish and South American researchers, so they could develop their studies and research and thereby consolidate Byzantine and modern Greek studies in Spain.

The aim of the Centre was to make the Spanish-speaking world aware of the history and role of Byzantium as the continuity of the essential characteristics of the cultural heritage from ancient Greece and Rome, which are combined with Christian tradition and enriched with the fundamental principles and values of humanism, diplomacy and multiculturalism, elements which make up the political, economic and social reality of Europe.

The Centre of Byzantine, Modern Greek and Cypriot Studies (C.E.B.N.Ch.) in Granada was founded by the Greek State through the Greek Embassy in Spain in July 1998 and it functions as a research centre for the University of Granada. Its Governing Council consists of the Embassies of Greece and Cyprus in Spain, the University of Granada, the Ministry of Culture of the Autonomous Government of Andalusia and the Municipality of Adra (ancient Abdera), which participate as institutional members of Greece in Spain. Activities of the centre focus primarily on research, teaching, publications and cultural events.

It should be pointed out that the Centre for Byzantine Studies houses the biggest and most specialized library for Byzantine and Modern Greek Studies in Europe, outside Greece and Cyprus. Among its more than 30,000 titles available to the public, the library has important publications on Byzantine language, history, literature, philosophy and art, as well as historiographical Byzantine sources, both in their original language and in translation. A large collection of studies about Modern Greek literature and works of the most important Modern Greek authors translated into Spanish can also be found there. Finally, there is also a rich bibliography in Spanish about Greek and Balkan history which constitutes a useful resource for students studying the Byzantine and Modern Greek world.

In addition, the library houses one hundred specialist scientific journals available to students and researchers in the facilities of the Centre library.

It should be emphasized that the Centre of Byzantine, Modern Greek and Cypriot Studies hosted the Doctoral Programme of the University of Granada Medieval and Modern Greece: studies on its language, literature, history and civilization from 2004 until the implementation of the new Master's degree promoted by the Bologna Process in 2010. This was the only programme specializing on Byzantine and Modern Greek taught at the Spanish universities. Important evidence 
of the significance of the Centre is the number of doctoral theses of the mentioned Doctoral Programme focused on the world of Byzantium, which were submitted during the last fifteen years at the University of Granada. Students' research relied heavily on extensive bibliographic and documentary collection of the Centre. These doctoral theses cover different subjects of this period as the titles of some of them suggest:


Princes' in the Byzantine world as continuity of Isocratic rhetorical-political tradition; Byzantines, Sassanids, and Muslims. The end of the ancient world and the beginning of the Middle Ages in the East; The 'Vita Basilii' of the Continuer of Theophanes: between literature and history. Study of the work in its various dimensions; Literary and ideological significance in the Byzantine tradition of the 'Epic Panegyrics' of George of Pisidia; The influence of Byzantine historiography in 'Roman History' of Nicéforo Gregoras. All these works were published by the University of Granada Press and are available online. It should be noted that they significantly contribute to the field of Byzantine studies. They offer valuable information about studied authors, provide a thoroughly-researched context in which their works developed and present new material and perspectives for future research.

The library has received donations from important Greek personalities and intellectuals, and the Centre houses the personal library of the intellectual and ex-President of the Greek Republic Constantine Tsatsos, the literary library of Konstantinos Delopoulos and a large part of the library of Isadora Rosenthal-Kamarineas. Thanks to the research project about travel literature, the Centre owns the richest collection of original nineteenth- and twentieth-century editions about Spanish travellers in Greece, the Ottoman Empire, the Balkans and the Holy Land.

In addition to the material described above, the archival material includes: the digital archive of Ioannis Chassiotis, including records of the Greek and Spanish relations during Turkish domination. Origin: Spanish archives; Greek documents (in digital format) concerning the diplomatic relations between Greece and Spain. Origin: General State Archives (Greece); Photographic material of the Byzantine monuments of Constantinople (more than 100,000 photographs).

The Centre's facilities constitute the home base for the research group Studies of Medieval and Modern Greek Civilisation (HUM 728) at the University of Granada, which carries out different projects (Centre of Byzantine, Modern Greek and Cypriot Studies 2015a).

The projects which focus on Byzantine studies are:

- Archive/database of Greek historiographical sources. 4th - 7th century;

- Library of Byzantine texts;

- Archive/database of Spanish sources on Byzantium, Modern Greece and Cyprus;

- Archive/database of sources on Byzantine-Slavic relations. A` and B`phases.

\section{Archive/database of Greek historiographical sources. 4th - 7th century}

Byzantine historiography is the main source for the study of the history of Byzantium and it is one of the most interesting genres of Byzantine literature. Despite following traditional models concerning style and language, it has an original element which is not present in other literary genres such as rhetoric, which is especially prolific in Byzantium. Being aware of this, the research group Studies of Medieval and Modern Greek Civilisation (HUM 728) proceeded to create the programme Archive/database of Greek historiographical sources: 4th - 7th century. During the first phase of the project, biographical data and the works of the most important Byzantine historiographers from the 4 th to the 7 th centuries were collected. A database was created on 
the project website the aim of which was to disseminate information about these authors in the Spanish language among the academic community. The project is expected to be extended until it covers all the centuries of Byzantium.

It is worth pointing out that there is no specific work in Spain about Byzantine historiography in general or about this period in particular. For this reason, the presentation of the authors of this time, their writings and their content, historical method, style, vocabulary, syntax and morphology, the presentation of manuscripts, editions, translations, updated bibliographies, etc., will be extremely useful in the field of Greek philology, because it will facilitate the study of classical genres during the Byzantine period and it will give students and researchers the opportunity to improve their knowledge about Byzantium and its values.

The benefits of this project are clear if we consider that in many cases, researchers and teachers have no knowledge of Greek and that this tool is developed in Spanish, which facilitates its use, especially in teaching and research. It should be noted that trained philologists can directly read these Byzantine texts in Greek, but this might be impossible for others.

\section{Library of Byzantine Texts}

This project aims to respond to the lack of Byzantine sources in Spanish. Its fundamental goal is bilingual Greek-Spanish editions, with an introduction and commentary on selected works of Byzantine writers in order to make these Byzantine sources accessible to Spanish historians specializing in the Byzantine period, since they do not always have knowledge of Greek. As a result of this project, numerous bilingual editions of Byzantine historiographical sources have been already published, such as Versos del Gramático Señor Teodoro Pródromo el Pobre o Poemas Ptocoprodrómicos, Trenos por Constantinopla, Relato de cómo se construyó Santa Sofía según la descripción de varios códices y autores, Paulo el Silenciario. Un poeta de la corte de Justiniano, Fuentes Griegas sobre los Eslavos, Nicéforo Brienio. Materia de Historia, Jorge Acropolites. Narración histórica, La didascalia de Jacob, Agatías. Historias. Guerras en Italia y Persia, Parallela Minora Latinobyzantina. Las traducciones de Guarino de Verona y Constantino Láscaris (Centre of Byzantine, Modern Greek and Cypriot Studies 2015b). This project has also resulted in several post-graduate dissertations and doctoral theses which are published in bilingual editions, with the Greek text on odd pages, and the same content translated into Spanish on even pages. This allows for quick comparisons of texts with their translation which considerably increases accessibility of ancient texts for historians and philologists. All translations contain a preliminary study where information about the manuscripts is given and a detailed analysis of the text is carried out. The preliminary study also includes an introduction about the author, their biography and a detailed analysis of their work. Special importance is given to the study of the historical, social and literary framework in which the text was created and to the location of its sources. The language of the text is closely analysed: characteristics, style, narrative techniques, etc. are scrutinized. Linguistic commentary is thorough and detailed and includes the analysis of the nominal, pronominal and verbal morphological system, and the analysis of the metre, in case the text is in verse. The aim is not only to provide access to the texts for researchers or general readers, but also to promote understanding of the historical, social and literary context in which the texts developed, to examine its importance at the time of creation, and to assess its contribution to our current knowledge of Byzantium. 


\section{Archive/database of Spanish sources for Byzantium, Modern Greece and Cyprus}

This project started in 2008 with funding from the Hellenic Ministry of Education and Religious Affairs and the Ministry of Education and Culture of Cyprus and its main objective is the localization, digitalization, study and publication of archival, literary and artistic Spanish sources dealing with Byzantium, modern Greece and Cyprus. This undertaking has given rise to important works which have been published and to others which are currently being prepared for publication.

A corpus with Spanish sources is being created with a fairly broad chronological framework that ranges from the 13th century to the early 20th century. The aim of this project is to present the relationships between Greece and Spain and to offer valuable information about them. In successive phases, the project will deal with the location of Greek manuscripts in Spanish libraries. Another fundamental aspect covered by the project is the Spanish interest in the Greek civilisation, by analysing the manuscripts of Greek authors. In Spain, these historical sources have opened important avenues for research on the history of Greece from Byzantine times to the present day. This research has focused on the collections and documents of the General Archive of Simancas and others like the General Archive of the Indies and the Archives of the Spanish Ministry of Foreign Affairs (Osorio 2011).

\section{Archive/database of sources for the Byzantine-Slavic relations. $A^{\prime}$ and $B^{\prime}$ phases}

This project, financed by the Autonomous Government of Andalusia, was carried out in two phases. The aim of the first phase was to localize, translate and comment on the texts about the emergence and installation of the Slavs in the Balkan Peninsula, working primarily with the testimonies of Byzantine authors about the first groups of Slavs who arrived in the Balkan Peninsula after crossing the Danube between the 6th and 8th centuries (Morfakidis Filactós Casas Olea, 2009). As a result, a corpus of short passages from the work of Byzantine authors, such as Procopius of Caesarea, John Malalas, Agathias Scholasticus, Menander Protector, Patriarch Nicephorus, etc., was created. In the second phase, the focus shifted on the texts about Christianization and the spread of Byzantine Culture in the Rus' and among the Bulgarians and their relations to Byzantium. The relations between Byzantium and the Slavs who had settled in the south of the Danube in the 8th century, and who from the 9th century rapidly expanded due to their contact with other northern Slavs, were studied. As a result of unique circumstances, the first Slavic States of the Balkans and north of the Black Sea were consolidated in just two centuries. However, it is important to emphasise that these States consolidated on common basis, namely on their Christianization and the imperial model of Byzantium. The corpus of the analysed texts included the updated versions of traditional editions of fundamental historiographical texts for the period with specific studies, based on the series of the editorial Brill East Central and Eastern Europe in the Middle Ages 450-1450. The corpus contains references to the work of specialists on the subject, such as František Dvorník, Ivan Dujčev, Alexis P. Vlasto, Gennadij G. Litavrin and Michail V. Bíbikov, whose research focuses on the central role that Byzantine-Slavic relations played in the history of Europe between 9th and 11th centuries (Casas Olea, 2020). Two important scholarly works were published as a result of this research: Greek Sources on the Slavs: Expansion and Establishment of the Slavs in the Balkan Peninsula (2009) and Greek Sources on the Slavs II. Christianization and Formation of the First Slavic States (2020). Both volumes - with the texts 
presented chronologically, with parallel translations into Spanish and with a detailed introduction to the historical context of Byzantine-Slavic relations - were published by the Center for Byzantine, Modern Greek and Cypriot Studies.

Finally, since 2000 the Centre has offered its services to the University of Granada by introducing Byzantine and Modern Greek Studies into the study programme of the Faculty of Arts and the Faculty of Translation and by providing the University with teaching staff and teaching material.

Teaching is focused on:

- Byzantine language and literature;

- Byzantine historiography;

- Byzantine sources about the Slavic world.

It is important to highlight that numerous international conferences and workshops, as well as important exhibitions in Granada and other Spanish cities (such as Journey to Mount Athos and The Civilization of the Logos. 3500 Years of the History of Greek Language) have been funded by the Centre for Byzantine Studies.

In conclusion, all these activities are carried out with the ultimate purpose to promote and disseminate the values and richness of Byzantine culture, not only among students and scholars, but also among the wider public. In Western Europe, Byzantine culture and history were until recently an unknown world accessible to a few. In recent years, teachers and researchers have worked hard to transmit the knowledge about immense cultural wealth that Byzantium has left us. In this sense, the Centre for Byzantine Studies, supported by the Research Group Studies of Medieval and Modern Greek Civilization, has become an important platform for the defence and spread of Byzantine values and culture.

\section{REFERENCES}

Bádenas de la Peña, Pedro. 1993. Los estudios bizantinos en España [The Byzantine studies in Spain] in La filologia medievale e umanistica greca e latina nel secolo XX. Roma, 753-768.

Casas Olea, Matilde. 2020. Fuentes griegas sobre los eslavos II. Cristianización y formación de los primeros Estados eslavos [Greek sources on the Slavs 2nd. Christianization and formation of the first Slavic states]. Granada, 11-12.

Centre of Byzantine, Modern Greek and Cypriot Studies. 2013. Centre of Byzantine, Modern Greek and Cypriot Studies. http://www.centrodeestudiosbnch.com/en.

Centre of Byzantine, Modern Greek and Cypriot Studies. 2015a. Centre of Byzantine, Modern Greek and Cypriot Studies. http://www.centrodeestudiosbnch.com/en/pagina/769.

Centre of Byzantine, Modern Greek and Cypriot Studies. 2015b. Centre of Byzantine, Modern Greek and Cypriot Studies. http://www.centrodeestudiosbnch.com/en/pagina/91.

Fernández Galiano, Manuel. 1989. España. Los estudios clásicos durante el siglo XX [Spain. The Classic studies in 20th century]. In La Filologia greca e latina nel secolo XX. Pisa, 163-234.

Morfakidis Filactós, Moschos - Casas Olea, Matilde. 2009. Fuentes griegas sobre los eslavos I. Expansión y establecimiento de los eslavos en la Península Balcánica [Greek sources on the Slavs 1st. Expansion and establishment of the Slavs in the Balkan Peninsula]. Granada, 7-21.

Osorio $M^{a}$ J. 2011. La presencia del mundo griego en los fondos bibliográficos de España. Perspectivas de investigación [The presence of the Greek world in Spanish bibliographic collections. Research perspective], Granada, 11-13. 
Zozulak, Ján. 2017. Štúdium byzantskej filozofie v Európe a na Slovensku [The Research of Byzantine Philosophy in Europe and Slovakia]. In Konštantínove listy [Constantine's Letters] 10/1, 3-11.

\author{
Assistant Professor Mila García Amoró \\ University of Granada Faculty of Arts \\ Department of Greek Philology \\ Centre of Byzantine, Modern Greek and Cypriot Studies \\ Campus Universitario de Cartuja, s/n \\ 18071 Granada \\ Spain \\ maila@ugr.es \\ Assistant Professor Panagiota Papadopoulou \\ University of Granada Faculty of Arts \\ Department of Greek Philology \\ Centre of Byzantine, Modern Greek and Cypriot Studies \\ C/Gran Vía 9 - 2A \\ 18001 Granada \\ Spain \\ papadopoulou@ugr.es
}

